\title{
Evaluation of Fuzzy Logic Subsets Effects on Maximum Power Point Tracking for Photovoltaic System
}

\author{
Shahrooz Hajighorbani, ${ }^{1,2}$ M. A. M. Radzi, ${ }^{1,2}$ M. Z. A. Ab Kadir, ${ }^{1}$ S. Shafie, \\ Razieh Khanaki, ${ }^{1,2}$ and M. R. Maghami ${ }^{1,2}$ \\ ${ }^{1}$ Department of Electrical and Electronic Engineering, Faculty of Engineering, Universiti Putra Malaysia, \\ 43400 Serdang, Selangor, Malaysia \\ ${ }^{2}$ Center of Advanced Power and Energy Research (CAPER), Malaysia
}

Correspondence should be addressed to Shahrooz Hajighorbani; shahrooz.kntu@yahoo.com

Received 23 January 2014; Accepted 8 August 2014; Published 2 September 2014

Academic Editor: Gopal N. Tiwari

Copyright (C) 2014 Shahrooz Hajighorbani et al. This is an open access article distributed under the Creative Commons Attribution License, which permits unrestricted use, distribution, and reproduction in any medium, provided the original work is properly cited.

Photovoltaic system (PV) has nonlinear characteristics which are affected by changing the climate conditions and, in these characteristics, there is an operating point in which the maximum available power of PV is obtained. Fuzzy logic controller (FLC) is the artificial intelligent based maximum power point tracking (MPPT) method for obtaining the maximum power point (MPP). In this method, defining the logical rule and specific range of membership function has the significant effect on achieving the best and desirable results. This paper presents a detailed comparative survey of five general and main fuzzy logic subsets used for FLC technique in DC-DC boost converter. These rules and specific range of membership functions are implemented in the same system and the best fuzzy subset is obtained from the simulation results carried out in MATLAB. The proposed subset is able to track the maximum power point in minimum time with small oscillations and the highest system efficiency (95.7\%). This investigation provides valuable results for all users who want to implement the reliable fuzzy logic subset for their works.

\section{Introduction}

Fossil fuel is a very common choice in many countries worldwide due to its large sources, but nowadays by increasing concerns about some issues such as fossil fuel storage, global warming, and skyrocketing oil costs, it is desirable to consider substitute possible energy source that has high productivity and low outpouring $[1,2]$.

All of the PV systems have some main problems affected by weather conditions such as dirt, changing irradiation, temperature, and other factors. The PV systems have two main characteristics, $P-V$ and $I-V$, where $P, V$, and $I$ are PV output power, voltage, and current, respectively. Changing the irradiation has the most effect on these characteristics.

The PV system has an operating point that can be specified by the crossing point between $I-V$ curve of the PV panel and load line in $I-V$ characteristic. The variation of some factors such as irradiation, temperature, and dust can change the operating point. There is single point in $I-V$ and
$P-V$ curves of $\mathrm{PV}$ panel that power poses the maximum value and it is called maximum power point (MPP) [3]. In changing weather condition such as irradiation, the MPP controller should be capable of tracking MPP at minimum time in order to minimize the power loss.

In order to find the MPP, various methods have been proposed which can be classified in two general methods: conventional and soft computing methods. Conventional methods include perturb and observe (P\&O), constant voltage (CV), and conductance increment (IC), and soft computing methods cover fuzzy logic controller, neural network predictor, genetic algorithm, and so on [4-12]. Every tracking control method has its advantages and disadvantages. One of the main factors for finding the best MPPT algorithm is that the MPP should be found by controller in the minimum time especially under changing condition. Another significant factor is that the controller can operate at this point with minimum oscillation. The conventional methods have drawbacks such as low tracking speed and also oscillation 


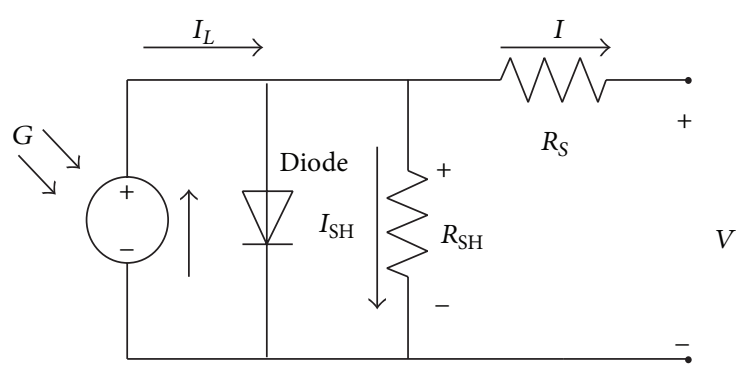

Figure 1: Equivalent circuit of a PV cell.

around MPP $[13,14]$. In order to solve this problem, the artificial intelligent method such as fuzzy logic (FL) can be used which keeps strength in changing weather condition such as temperature and radiation. In fuzzy logic method the main points are defining a rule table and the related range of membership function. The rules are defined according to specific range of membership functions and vice versa. By changing the range of membership functions, the rules can be changed for obtaining the expected result and, also, by changing the rules, the range of membership functions should be changed.

In this paper, in Section 2 the PV system is explained and modeled by MATLAB in base of the KC200GT panel type. In Section 3 the DC-DC boost converter is explained. In Sections 4 and 5, fuzzy logic controller (FLC) and different subsets for this method are explained. Then, in Section 6, the results of simulations are analyzed. Finally, the last section concludes and discusses the results of simulations for studied fuzzy rules subsets.

\section{Photovoltaic System}

2.1. Equivalent Model of Photovoltaic System. In Figure 1, the tantamount circuit for PV cell is shown that is relative to the incident radiation which is connected in parallel with shunt resistance $\left(R_{\mathrm{SH}}\right)$ and diode. The internal series resistance $\left(R_{S}\right)$ can be considered for modeling the internal losses that are created by the flowing current and also connection between cells [15].

The PV efficiency is so sensitive to variation of the series resistance such that a small changing in value of $R_{S}$ has a big effect on PV characteristics such as power and voltage. On the other hand, the effect of shunt resistance on PV efficiency can be ignored because the PV efficiency is not responsive to changing of $R_{\mathrm{SH}}$, so the shunt resistance can be assumed to be almost infinite and it becomes open circuit. By these assumptions, the net current of a cell can be defined by (1) and $I-V$ characteristic can be described according to

$$
I=I_{L}-I_{o}\left(\exp \left(\frac{q\left(V+R_{S} \cdot I\right)}{n \cdot K \cdot T}\right)-1\right) .
$$

In (1), $I$ and $V$ are the output solar cell current and voltage, respectively. $I_{o}$ and $I_{L}$ are the cell saturation and photocurrent, respectively. In this equation, there are some constant coefficients: $K\left(=1.38 \times 10^{-23} \mathrm{~J} / \mathrm{K}\right)$ is a Boltzmann's
TABLE 1: Specifications of solar KC200GT at $1000 \mathrm{~W} / \mathrm{m}^{2}$ and $25^{\circ} \mathrm{C}$.

\begin{tabular}{lc}
\hline Parameters & Values \\
\hline Power in maximum point, MPP & $200 \mathrm{~W}$ \\
Voltage in maximum point, $V_{\mathrm{MPP}}$ & $26.3 \mathrm{~V}$ \\
Current in maximum point, $I_{\mathrm{MPP}}$ & $7.61 \mathrm{~A}$ \\
Open circuit voltage, $V_{\mathrm{OC}}$ & $32.9 \mathrm{~V}$ \\
Short circuit current, $I_{\mathrm{SC}}$ & $8.21 \mathrm{~A}$ \\
Temperature coefficient of $V_{\mathrm{OC}}$ & $-0.123 \mathrm{~V} / \mathrm{K}$ \\
Temperature coefficient of $I_{\mathrm{SC}}$ & $0.0032 \mathrm{~A} / \mathrm{K}$ \\
Number of cells per module & 54 \\
\hline
\end{tabular}

constant, $q\left(=1.6 \times 10^{-19} \mathrm{C}\right)$ is an electron charge, $n$ is the ideality factor that its value ranges are between 1 and 2, $T$ is the cell's working temperature, and $R_{S}$ is the series resistance that is explained before.

In order to draw the $I-V$ curve, (1) needs to be solved. This equation is nonlinear and, with the purpose of solving it, Newton Raphson's method as a numerical method is used.

In (1), there are some subequations such as saturation current, photocurrent, and open circuit current equations that are dependent on temperature. These subequations can be expressed as follows:

$$
\begin{gathered}
I_{L}=I_{L}\left(T_{1}\right)+K_{o}\left(T-T_{1}\right), \\
I_{L}\left(T_{1}\right)=I_{\mathrm{SC}}\left(T_{1}\right) \frac{G}{G_{\mathrm{ref}}} \\
K_{o}=\frac{I_{\mathrm{SC}}\left(T_{2}\right)-I_{\mathrm{SC}}\left(T_{1}\right)}{\left(T_{2}-T_{1}\right)}, \\
I_{o}=I_{o}\left(T_{1}\right) \times\left(\frac{T}{T_{1}}\right)^{3 / n} \cdot \exp \left(\frac{q \times V_{g}\left(T_{1}\right)}{n \cdot K \cdot\left((1 / T)-\left(1 / T_{1}\right)\right)}\right), \\
I_{o}\left(T_{1}\right)=\frac{I_{\mathrm{SC}}\left(T_{1}\right)}{\left(\exp \left(q \times V_{\mathrm{OC}}\left(T_{1}\right) / n \cdot K \cdot T_{1}\right)-1\right)} .
\end{gathered}
$$

In these equations, $G$ is the irradiation and the band gap energy is shown by $V_{g}$ that its value is $1.12 \mathrm{eV}$ for silicon. The "ref" subscript recognizes the standard test conditions (STC) expressed in the IEC 61215 international standard [16]. According to this standard, $T_{\text {ref }}$ and $G_{\text {ref }}$ are equal to $25^{\circ} \mathrm{C}$ ( $T_{1}$ in equations) and $1000 \mathrm{~W} / \mathrm{m}^{2}$, respectively. $V_{\mathrm{OC}}$ and $I_{\mathrm{SC}}$ in reference temperature are specified in PV panel data sheet.

As mentioned before, series resistance has a big effect on the PV characteristics. Gow and Manning first time defined (3) in order to calculate the value of series resistance $\left(R_{S}\right)$ [17]. This equation is obtained by differentiating (1) and evaluating it in open circuit conditions:

$$
\begin{gathered}
R_{S}=-\left[\frac{d V}{d I_{V_{\mathrm{OC}}}}+\frac{1}{X_{V}}\right] \\
X_{V}=I_{o}\left(T_{1}\right) \cdot \frac{q}{n \cdot k \cdot T_{1}} \cdot \exp \left(\frac{q \cdot V_{\mathrm{OC}}\left(T_{1}\right)}{n \cdot K \cdot T_{1}}\right) .
\end{gathered}
$$




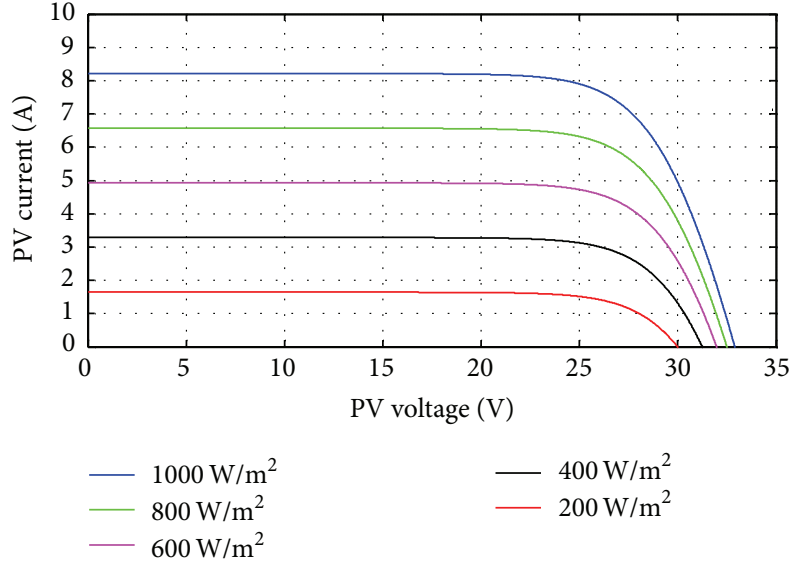

FIGURE 2: $I$ - $V$ output characteristic with different irradiance.

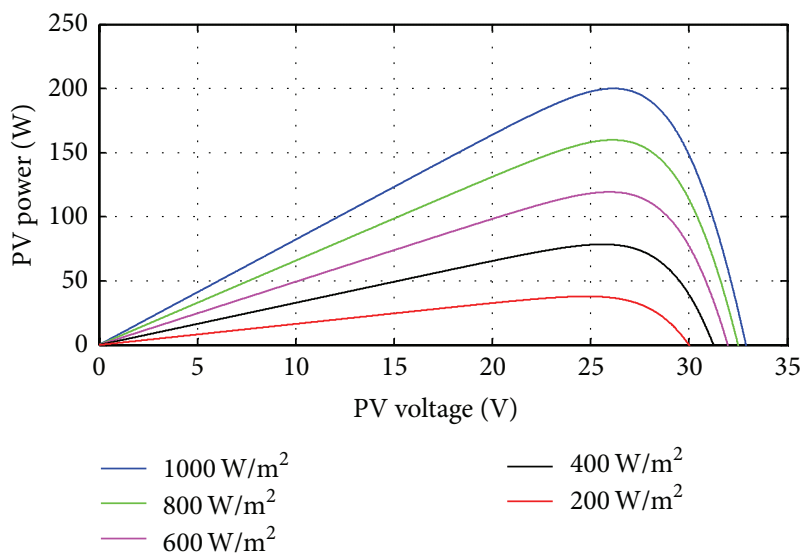

Figure 3: $P-V$ output characteristic with different irradiance.

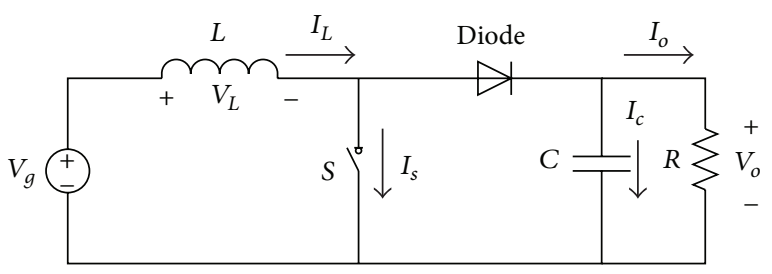

FIgURE 4: The boost converter.

2.2. Electric Characteristic of Photovoltaic System. In this paper, simulation results are based on the KC200GT panel. In Table 1, the key specifications of this panel are shown according to datasheet [18].

In the previous section, it was mentioned that $I-V$ and $P-V$ characteristics of the PV system depended on irradiance $(G)$ and temperature. In Figures 2 and 3 , the $I-V$ and $P-V$ curves of the KC200GT PV module in different irradiations and fixed temperature $\left(25^{\circ} \mathrm{C}\right)$ are shown. As shown in Figure 3, the maximum power point is decreased by decreasing the irradiation. The maximum power in $1000 \mathrm{~W} / \mathrm{m}^{2}$ irradiation is 200 watts.

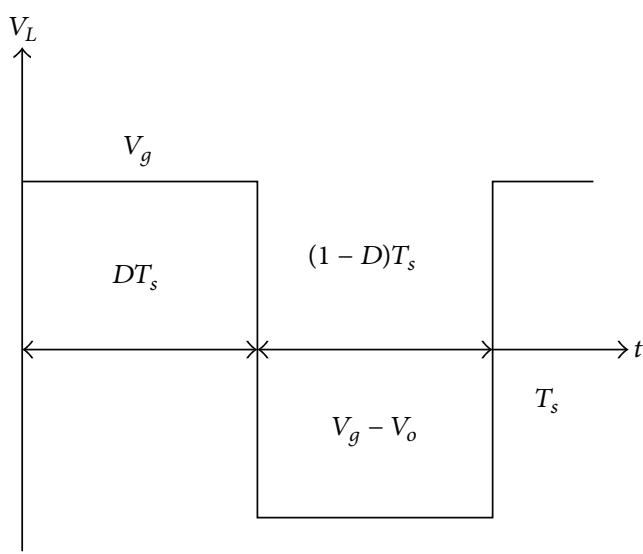

FIGURE 5: Voltage waveform of the boost converter's inductor.

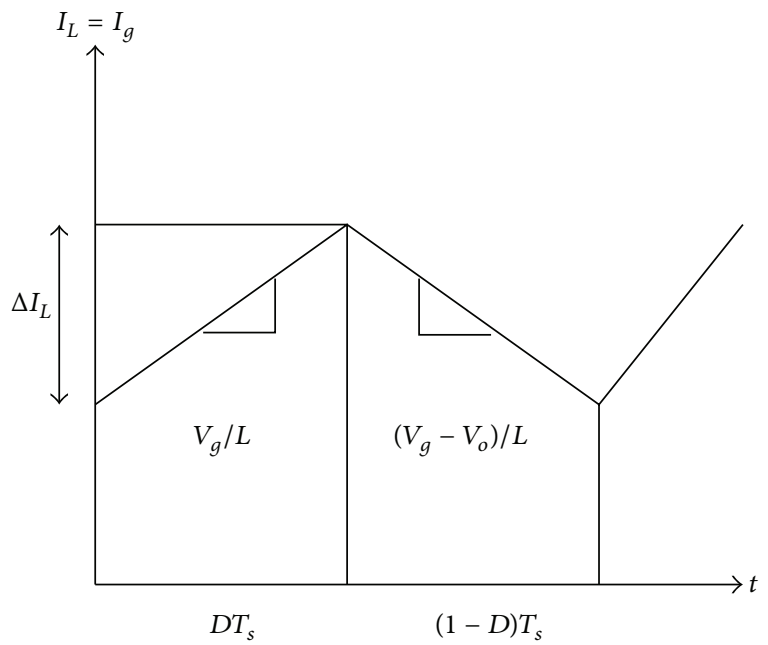

FIGURE 6: Current waveform of the boost converter's inductor

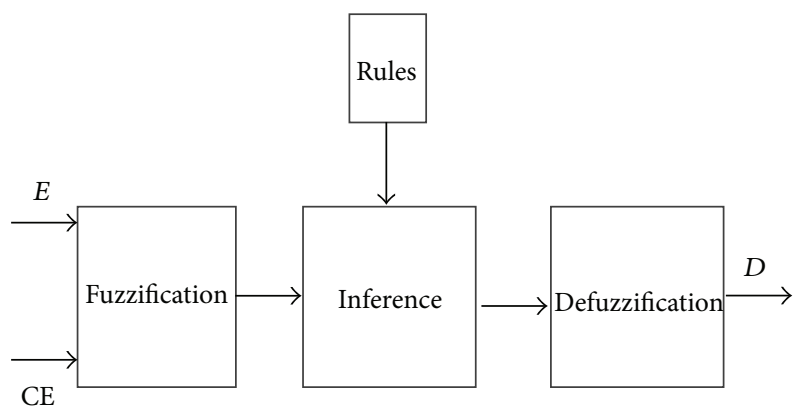

FIGURE 7: Fuzzy logic diagram.

\section{DC-DC Boost Converter}

The boost converter is a famous switched-mode converter where its produced output voltage is bigger than dc input voltage in extent. The ideal and simple form of this converter is shown in Figure 4 that is including switch and diode for switching the system.

When the switch is ON (first subinterval) diode, capacitor, and load are connected to ground and the inductor is 


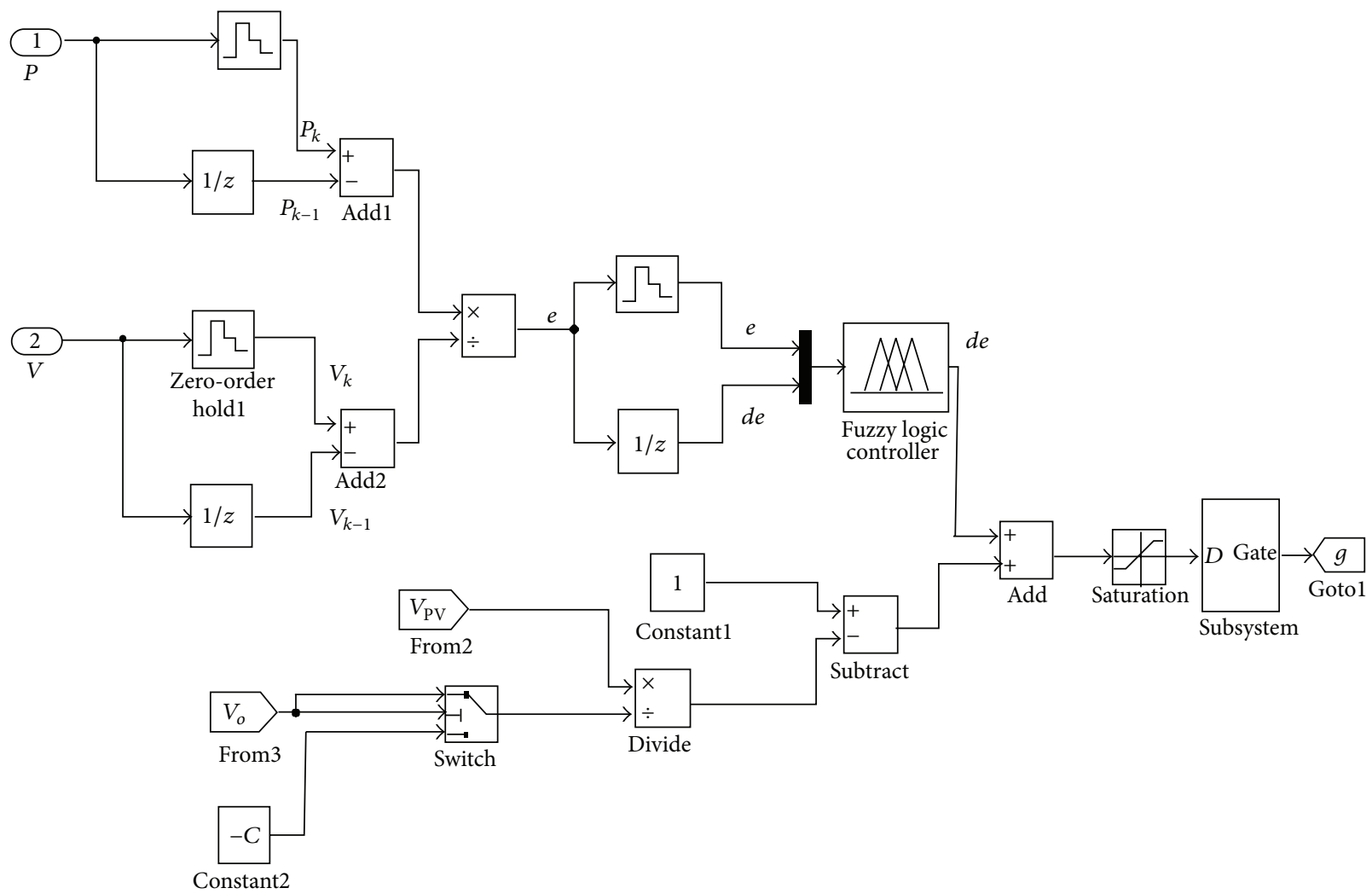

Figure 8: Fuzzy logic controller (FLC).

TABLE 2: The twenty-five fuzzy rules of the first fuzzy subset (S1).

\begin{tabular}{llllll}
\hline$E$ & & & CE & & \\
& NB & NS & ZE & PS & PB \\
\hline NB & ZE & ZE & PB & PB & PB \\
NS & ZE & ZE & PS & PS & PS \\
ZE & PS & ZE & ZE & ZE & NS \\
PS & NS & NS & ZE & ZE & ZE \\
PB & NB & NB & ZE & ZE & ZE \\
\hline
\end{tabular}

TABLE 3: The twenty-five fuzzy rules of the second fuzzy subset (S2).

\begin{tabular}{llllll}
\hline$E$ & & & CE & & \\
& NB & NS & ZE & PS & PB \\
\hline NB & ZE & ZE & PB & PB & PB \\
NS & ZE & ZE & PS & PS & PS \\
ZE & PS & ZE & ZE & ZE & NS \\
PS & NS & NS & ZE & ZE & ZE \\
PB & NB & NB & ZE & ZE & ZE \\
\hline
\end{tabular}

charged through the input voltage source $\left(V_{g}\right)$. In this subinterval, load is supplied by capacitor and the inductor current is increased. When the switch is off (second subinterval), the load is supplied by inductor current and additionally recharges the capacitor.

In Figures 5 and 6, voltage and current of the boost converter inductor are shown. According to these two figures
TABLE 4: The twenty-five fuzzy rules of the third fuzzy subset (S3).

\begin{tabular}{llllll}
\hline$E$ & & & CE & & \\
& NB & NS & ZE & PS & PB \\
\hline NB & PB & PB & PB & PS & ZE \\
NS & PB & PB & PS & ZE & NS \\
ZE & PB & PS & ZE & NS & NB \\
PS & PS & ZE & NS & NB & NB \\
PB & ZE & NS & NB & NB & NB \\
\hline
\end{tabular}

and also using the principles of voltage and ampere second balance [19], the voltage conversion ratio $M(D)$ and the converter elements values are obtained. The voltage conversion ratio is defined as a proportion of the output voltage to input voltage of boost converter:

$$
M(D)=\frac{V}{V_{g}}=\frac{1}{(1-D)},
$$

where $V_{g}$ and $V$ are the input and output voltages of the boost converter and $D$ is duty cycle that is defined as a ratio of the $\mathrm{ON}$ duration to the switching time period and it is adjusted by controller that in this case is fuzzy logic controller.

It can be noticed that when the boost converter is connected to PV panel, by increasing the duty cycle, the input voltage and current are decreased and increased, respectively, and it leads to shifting the operating point to the left side of the $P-V$ curve of the PV panel. In a similar manner, by decreasing 

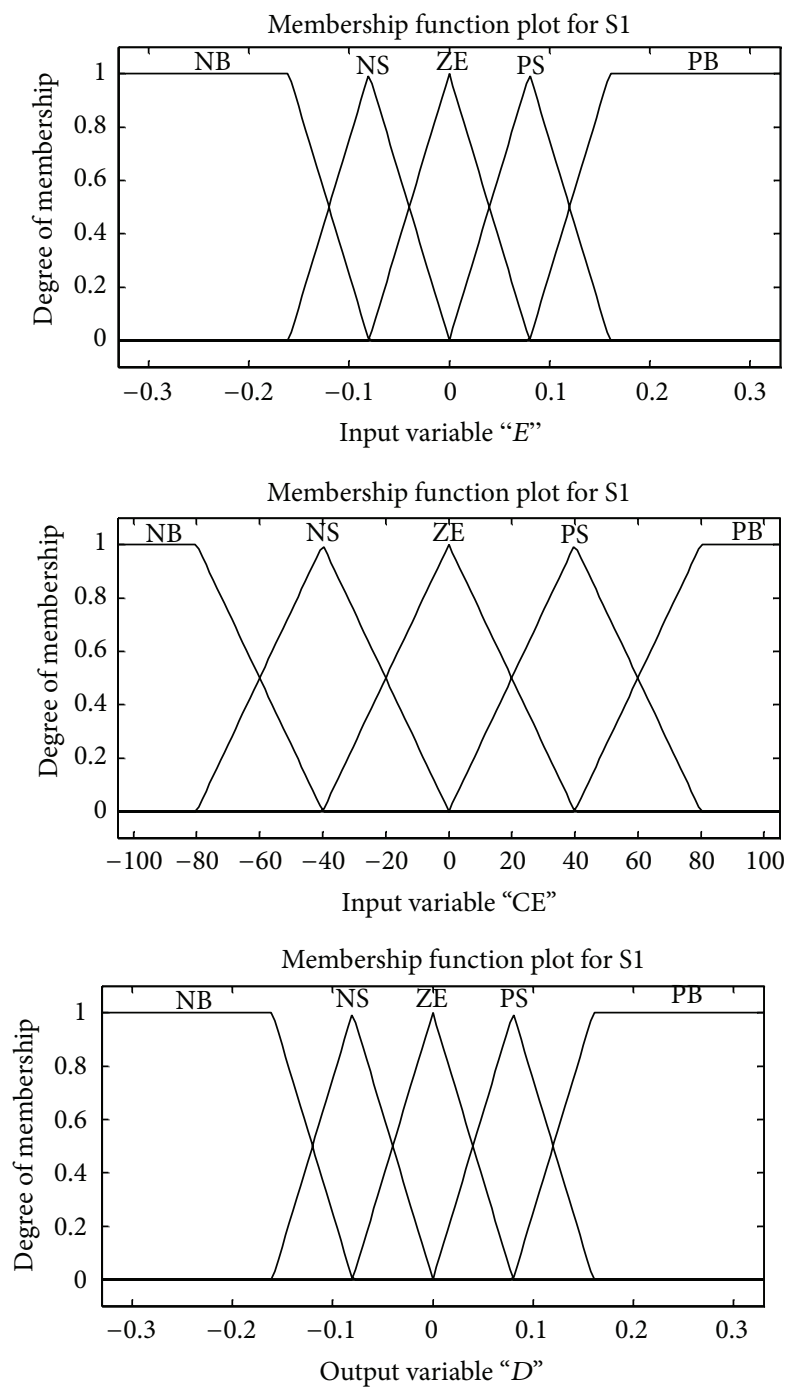

Figure 9: The membership functions of $E, C E$, and $D$ for S1.

the duty cycle, the input voltage and current are increased and decreased, respectively, and it leads to shifting the operating point to the right side of the $P-V$ curve of the PV panel.

\section{Fuzzy Logic Controller (FLC)}

Fuzzy logic (FL) is a strategy of processing degrees of truth instead of Boolean logic. The fuzzy logic rules were first proposed by Professor L. Zadeh in 1965 and can be implemented for the complex and unknown systems. The conventional methods are not satisfied for the system especially for nonlinear and complex systems and cannot obtain the desirable results. The FL systems are more flexible rather than classical and conventional methods and they are capable of modelling and approximating the nonlinear systems.

The structure of the fuzzy logic systems is based on the changing the control linguistic to form of the if-then in an automatic control system and a good knowledge and experience can be more useful instead of understanding a technical behavior and model of system [20-22].
As mentioned in previous sections, the conventional methods such as $\mathrm{P} \& \mathrm{O}$ have some drawbacks such as oscillation around the MPP and also take a long time to obtain the steady state, so in this paper the fuzzy logic control method is considered for maximum power point in order to evaluate the best structure of the interface and rules for obtaining the best fuzzy subset rules. The fuzzy logic diagram is shown in Figure 7 that is including two inputs and one output. The inputs of the FLC system are the error $(E)$ and change of error (CE) that are defined by (6). The output of FL is duty cycle $(D)$ that should operate to the boost converter [23, 24]. Consider

$$
\begin{gathered}
E(K)=\frac{P_{\mathrm{PV}(K)}-P_{\mathrm{PV}(K-1)},}{V_{\mathrm{PV}(K)}-V_{\mathrm{PV}(K-1)}} \\
\mathrm{CE}(K)=E(K)-E(K-1) .
\end{gathered}
$$

$V_{\mathrm{PV}}(k)$ and $P_{\mathrm{PV}}(k)$ are the $\mathrm{PV}$ voltage and power, respectively, at instant $k$. If $E$ will be positive it means that the operating point is in left side of the MPP and when it will be 

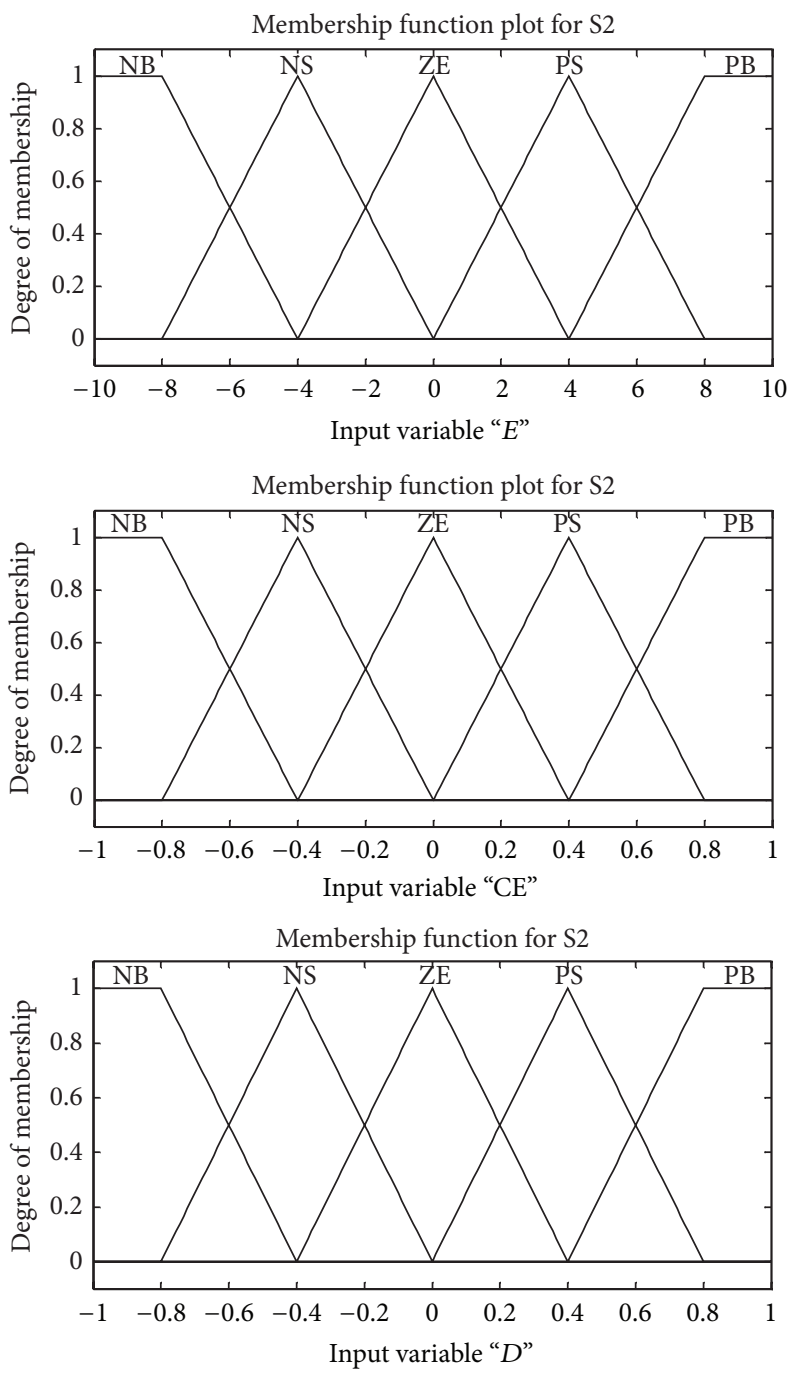

Figure 10: The membership functions of $E, \mathrm{CE}$, and $D$ for S2.

negative, the operating point is in right side of the MPP. The MPP will be obtained when $E$ is equal to zero. The moving direction in $I-V$ and $P-V$ curves is specified by CE [25-28].

The fuzzy logic fundamentally consists of three steps: fuzzification, rule base and inference engine, and defuzzification.

4.1. Fuzzification. In process of fuzzification, all variables used to describe the control rules should be converted to linguistic fuzzy labels. These variables are demonstrated in different fuzzy levels: PB (positive big), PM (positive medium), PS (positive small), ZE (zero), NB (negative big), NM (negative medium), and NS (negative small). In this study, different fuzzification subsets with different levels and membership function ranges are considered.

4.2. Rule Base and Inference Engine. Rules base is if-then functions that are used for the fuzzified inputs in order to apply for the controlled parameters. Defining these rules is dependent on operation of the system and experience. In this study, different subsets include forty-nine, thirty-five, and twenty-five fuzzy control rules with different specific range of membership functions being considered. Fuzzy inference engine is the process of devising the logical decision based on the rules. The fuzzy rules should be transferred into fuzzy linguistic output. In this work, Mamadani's fuzzy inference method has been used.

4.3. Defuzzification. In this stage, the output fuzzy data that is defined by the rules and inference engine should be converted to the numerical value by creating the union of the output from each rule. In this study, the center of gravity defuzzifier is used which is the common one.

\section{Fuzzy Logic Subsets}

As mentioned in previous section, implementing the fuzzy logic controller needs to have enough experience more than knowing the technical model of the system because in process of designing the fuzzy logic controller, rules and inference 

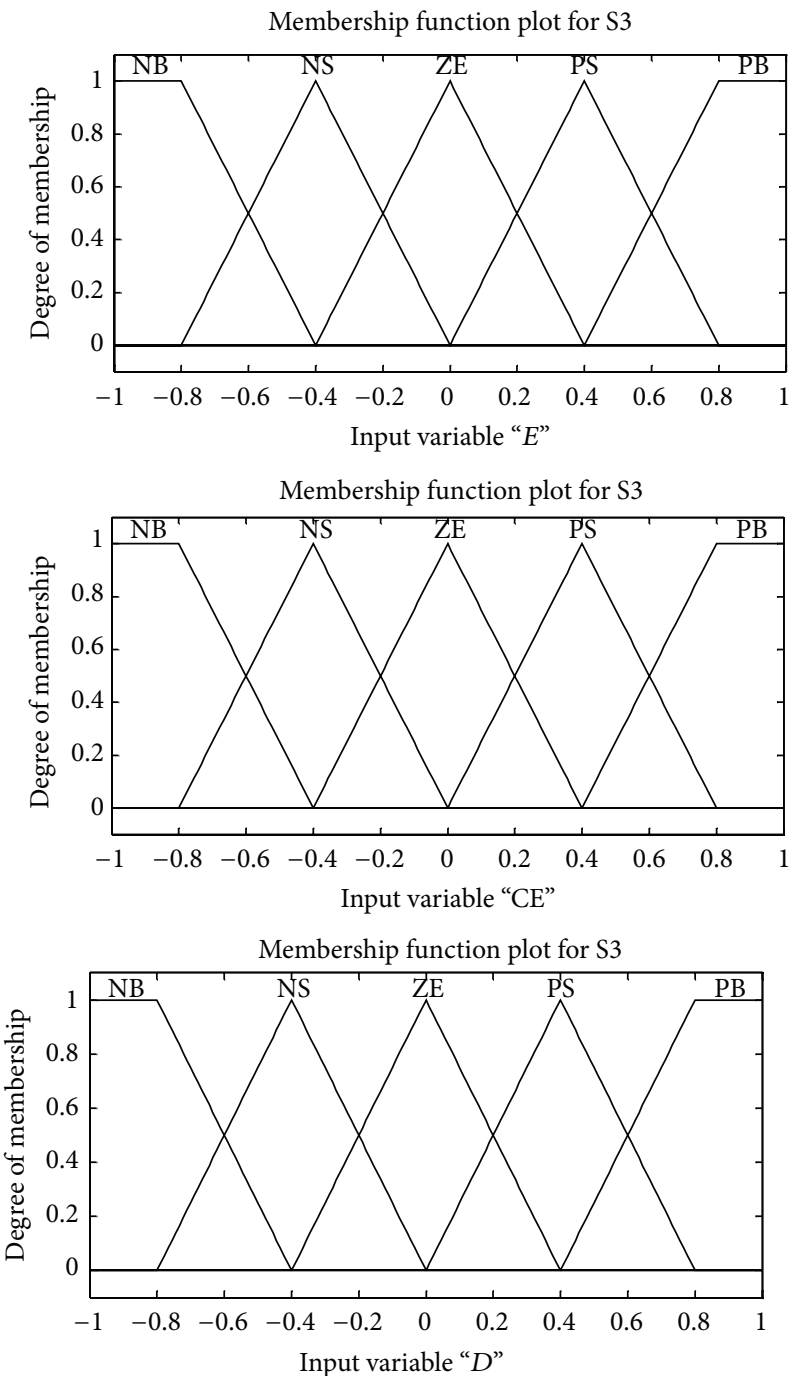

Figure 11: The membership functions of $E$, CE, and $D$ for $S 3$.

and also the range of membership functions are the important and crucial sections. Each fuzzy system has a subset rule that will be defined according to the specific range of membership function and vice versa [29-32]. In systems with the boost converter, different fuzzy logic subsets with different rules and range of membership functions have been used in order to obtain MPP. In each subset, range of membership function is defined according to the specific rule table and vice versa. In this paper, the main goal is to achieve the best fuzzy subset for obtaining MPP by comparative study of different common fuzzy subsets with considering main factors such as MPP's reaching time, oscillation, steady state time, ripple, efficiency, and some other factors. In this work, different subsets ( $\mathrm{S} 1$, S2, S3, S4, and S5) which include different rules and range of membership functions will be introduced and the best one will be selected.

For S1, S2, and S3, five subsets based on twenty-five rules have been used where their rules and membership functions are different. For S4, seven subsets based on forty-nine rules and, for S5, seven and five subsets based on thirty-five rules have been used. The triangular and trapezoid shaped membership functions have been used for all models. For the range of membership function, the oscillation of each signal has been checked and the best one is considered [33-35]. Figure 8 shows the fuzzy logic controller at which $E$ and CE are the inputs and $D$ is output of the controller.

5.1. First Subset (S1). It is as shown in Table 2 and Figure 9.

5.2. Second Subset (S2). It is as shown in Table 3 and Figure 10.

5.3. Third Subset (S3). It is as shown in Table 4 and Figure 11.

5.4. Fourth Subset (S4). It is as shown in Table 5 and Figure 12.

5.5. Fifth Subset (S5). It is as shown in Table 6 and Figure 13. 

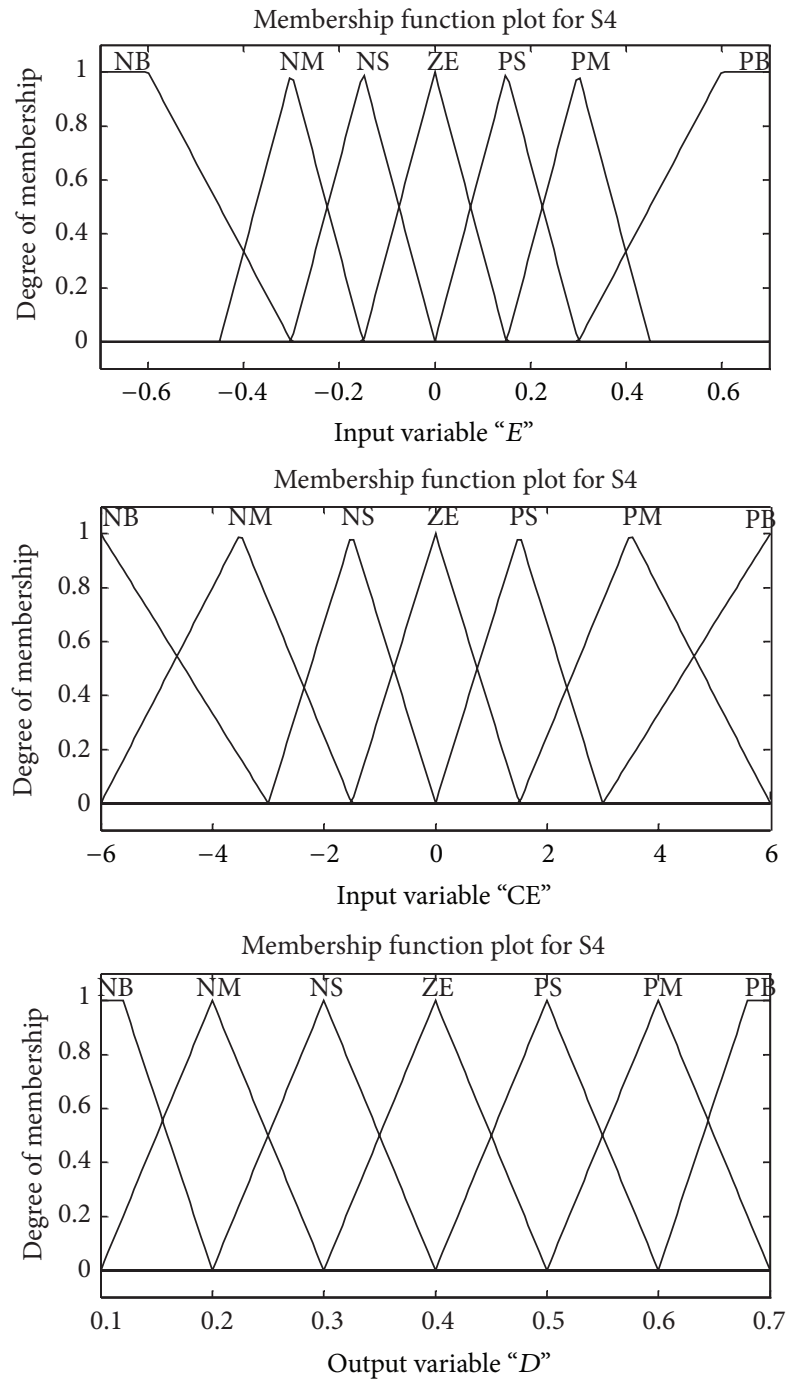

Figure 12: The membership functions of $E, C E$, and $D$ for $S 4$.

TABLE 5: The forty-nine fuzzy rules of the fourth fuzzy subset (S4)

\begin{tabular}{lccccccc}
\hline$E$ & & & \multicolumn{7}{c}{ CE } & \\
& NB & NM & NS & ZE & PS & PM & PB \\
\hline NB & ZE & ZE & ZE & NB & NB & NB & NB \\
NM & ZE & ZE & ZE & NM & NM & NM & NM \\
NS & NS & ZE & ZE & NS & NS & NS & NS \\
ZE & NM & NS & ZE & ZE & ZE & PS & PM \\
PS & PM & PS & PS & PS & ZE & ZE & ZE \\
PM & PM & PM & PM & ZE & ZE & ZE & ZE \\
PB & PB & PB & PB & ZE & ZE & ZE & ZE \\
\hline
\end{tabular}

\section{Simulation Result}

In this work, the simulations are carried out by MAT$\mathrm{LAB} /$ Simulink to validate the performance of the system. The source of the system is PV that is modeled by script in MATLAB. The five studied subsets are implemented in
TABLE 6: The thirty-five fuzzy rules of the fifth fuzzy subset (S5).

\begin{tabular}{llllll}
\hline$E$ & & & CE & & \\
& NB & NS & ZE & PS & PB \\
\hline NB & PB & PB & PS & PB & PB \\
NM & PB & PS & ZE & PS & PB \\
NS & PB & PS & PS & PS & PB \\
ZE & NS & NS & ZE & PS & PS \\
PS & NB & NS & NS & NS & NB \\
PM & NB & NS & ZE & NS & NB \\
PB & NB & NB & NS & NB & NB \\
\hline
\end{tabular}

control unit for the same system and performance of the system is considered for evaluation of the different fuzzy logic subsets. In Figure 14, the configuration of the system includes $\mathrm{PV}$, boost converter, and MPPT controller and input filter is shown. The input capacitance of the converter, $C_{\text {in }}$, is $2000 \mu \mathrm{F}$, the inductance, $L$, is $25 \mu \mathrm{H}$, the resistance of inductor, $R_{L}$, is 

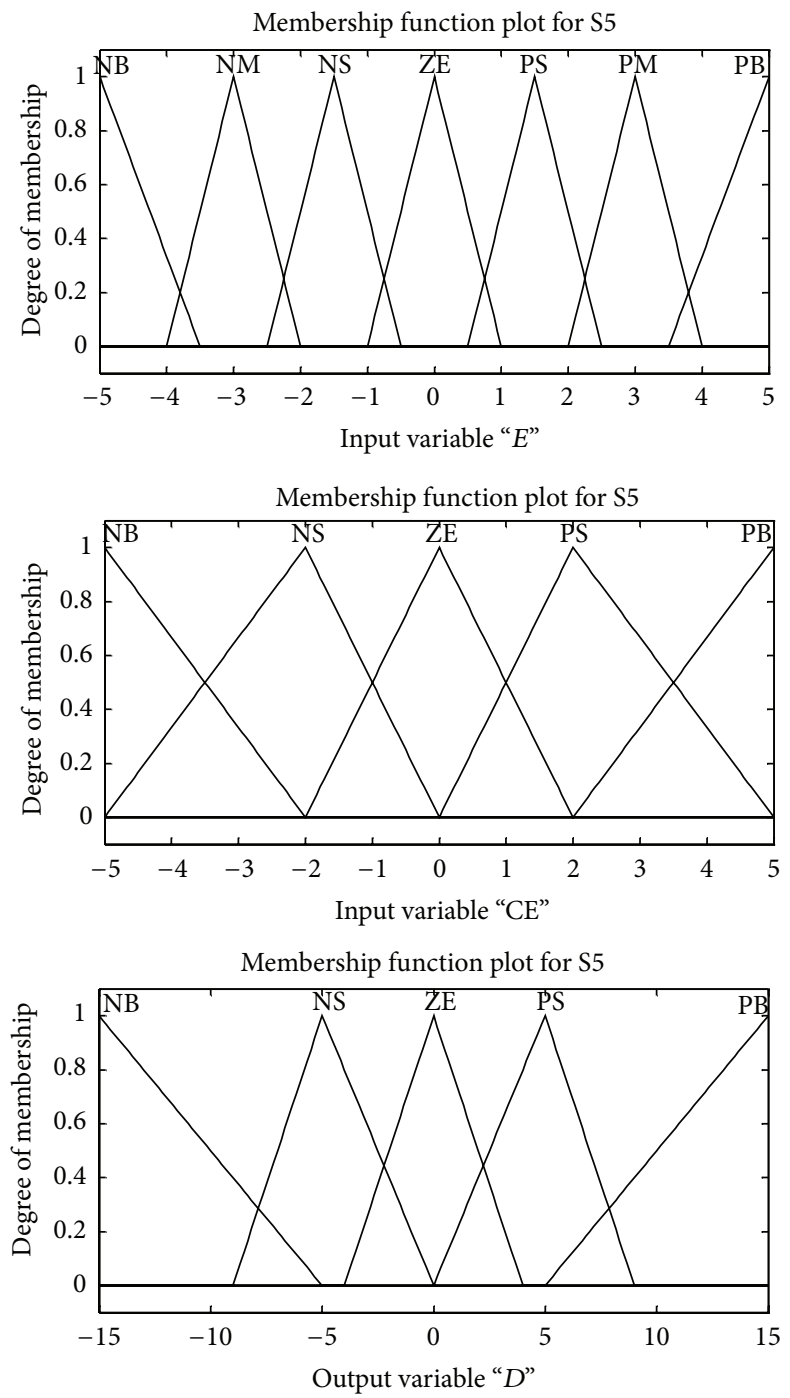

Figure 13: The membership functions of $E, \mathrm{CE}$, and $D$ for $\mathrm{S} 5$.

TABLE 7: The simulation values for PV variables.

\begin{tabular}{|c|c|c|c|c|c|c|c|c|c|c|}
\hline & $\begin{array}{c}P_{\text {ave }} \\
\text { PV }\end{array}$ & $\begin{array}{l}T_{1 P} \\
\mathrm{PV}\end{array}$ & $\begin{array}{l}T_{S P} \\
\mathrm{PV}\end{array}$ & $\begin{array}{c}P_{\text {ripp }} \\
\text { PV }\end{array}$ & $\begin{array}{c}P_{\text {ripp } S} \\
\text { PV }\end{array}$ & $\begin{array}{l}V_{\text {ave }} \\
\text { PV }\end{array}$ & $\begin{array}{l}T_{1 V} \\
\mathrm{PV}\end{array}$ & $\begin{array}{l}T_{S V} \\
\mathrm{PV}\end{array}$ & $\begin{array}{c}V_{\text {ripp }} \\
\text { PV }\end{array}$ & $\begin{array}{c}V_{\text {ripp_S }} S \\
\text { PV }\end{array}$ \\
\hline S1 & 200 & 0.0085 & 0.021 & 0.3 & 0 & 26.14 & 0.0085 & 0.021 & 0.52 & 0.12 \\
\hline S2 & 200 & 0.0085 & 0.01 & 1.2 & 0 & 26.09 & 0.0085 & 0.015 & 0.96 & 0.04 \\
\hline S3 & 199.3 & 0.0085 & 0.015 & 4.2 & 1.4 & 25.82 & 0.0085 & 0.015 & 1.76 & 1.03 \\
\hline S4 & 200 & 0.022 & 0.022 & 0 & 0 & 26.08 & 0.022 & 0.022 & 0.07 & 0.05 \\
\hline S5 & 199 & 0.0085 & 0.015 & 5.4 & 1.9 & 25.64 & 0.0085 & 0.015 & 1.76 & 0.96 \\
\hline
\end{tabular}

TABLE 8: The simulation values for boost converter variables.

\begin{tabular}{|c|c|c|c|c|c|c|c|c|c|c|}
\hline & $\begin{array}{c}P_{\text {ave }} \\
\text { Boost }\end{array}$ & $\begin{array}{c}T_{S P} \\
\text { Boost }\end{array}$ & $\begin{array}{l}P_{\text {ripp }} \\
\text { Boost }\end{array}$ & $\begin{array}{c}V_{\text {ave }} \\
\text { Boost }\end{array}$ & $\begin{array}{c}T_{S V} \\
\text { Boost }\end{array}$ & $\begin{array}{l}V_{\text {ripp }} \\
\text { Boost }\end{array}$ & $\begin{array}{c}I_{\mathrm{ave}} \\
\text { Boost }\end{array}$ & $\begin{array}{c}T_{S I} \\
\text { Boost }\end{array}$ & $\begin{array}{c}I_{\text {ripp }} \\
\text { Boost }\end{array}$ & $\eta_{T}$ \\
\hline S1 & 190.8 & 0.04 & 1.6 & 61.77 & 0.04 & 0.26 & 3.08 & 0.031 & 0.013 & $95.4 \%$ \\
\hline S2 & 191.35 & 0.04 & 0.7 & 61.86 & 0.04 & 0.1 & 3.09 & 0.032 & 0.005 & $95.7 \%$ \\
\hline S3 & 177.3 & 0.037 & 10.8 & 59.43 & 0.037 & 1.85 & 2.97 & 0.035 & 0.09 & $89 \%$ \\
\hline S4 & 190.2 & 0.05 & 1.1 & 61.6 & 0.05 & 0.19 & 3.08 & 0.036 & 0.009 & $95.1 \%$ \\
\hline S5 & 176.1 & 0.035 & 10.8 & 59.23 & 0.035 & 1.75 & 2.96 & 0.035 & 0.093 & $88.52 \%$ \\
\hline
\end{tabular}




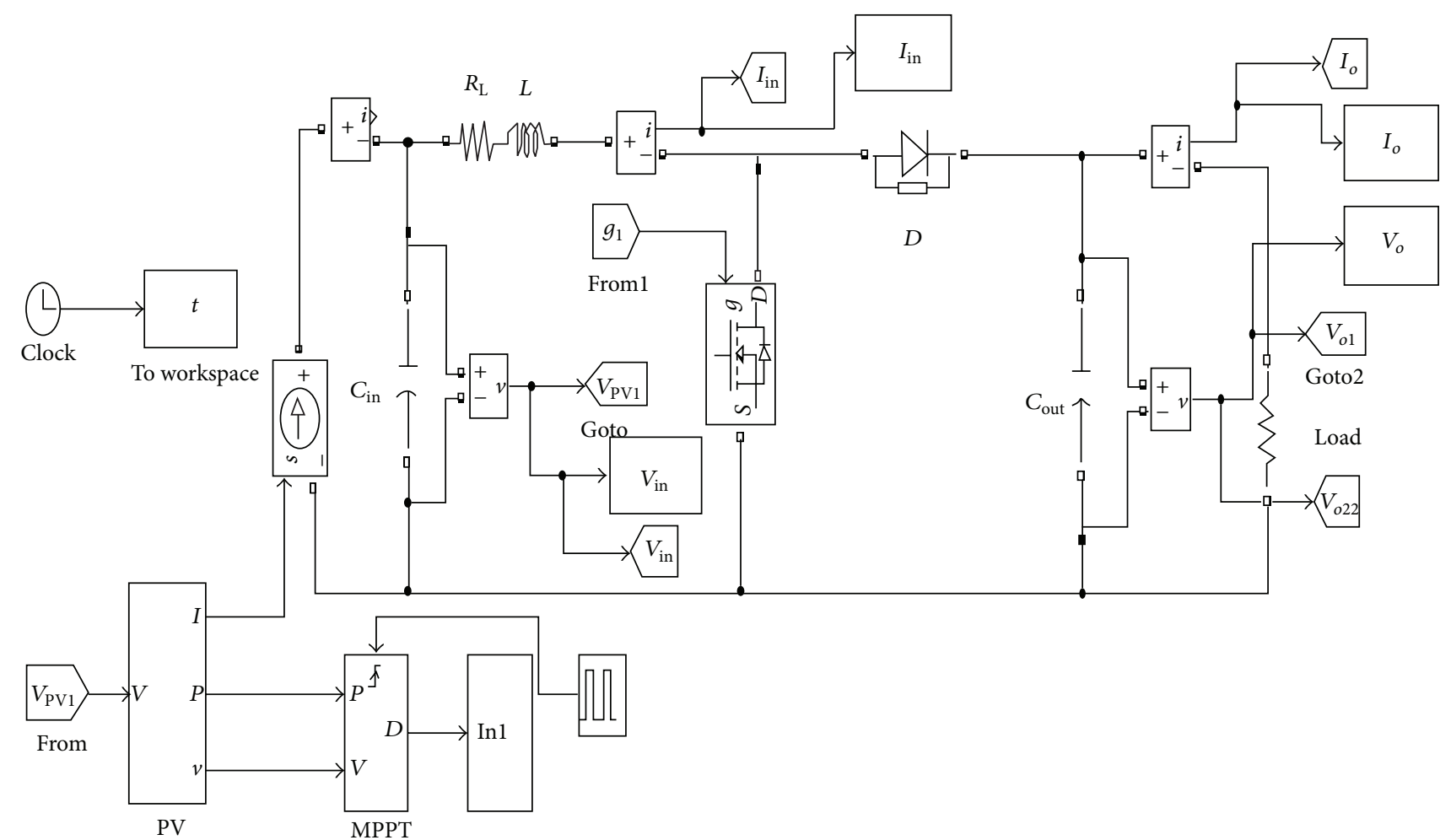

Figure 14: Configuration of the system.

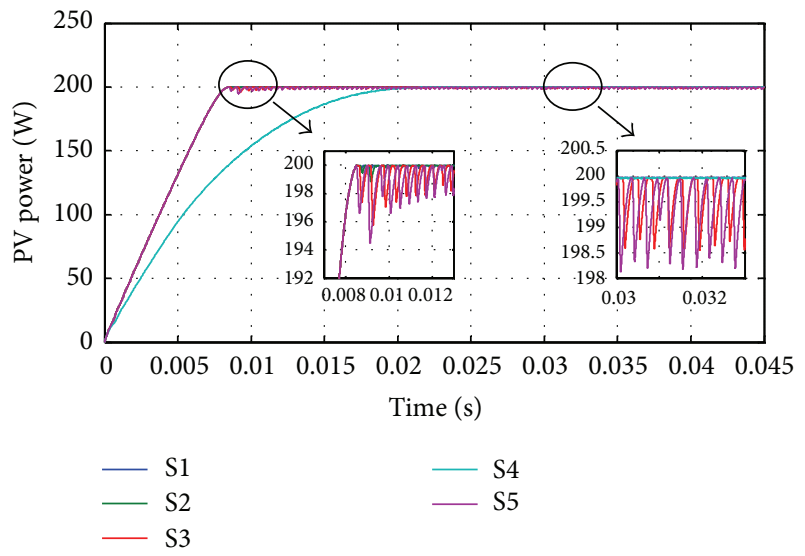

FIgURe 15: PV power at irradiation of $1000 \mathrm{~W} / \mathrm{m}^{2}$ and $25^{\circ} \mathrm{C}$.

$0.02 \Omega$, the output capacitance, $C_{\text {out }}$, is $450 \mu \mathrm{F}$, and the load resistance, $R$, is $20 \Omega$. The switching frequency of the system is $25 \mathrm{kHz}$.

For investigation and analyzing behavior of the system, there are some important factors which will be considered such as maximum power point reaching time, efficiency, and ripple in input and output voltage and power. The simulation values for these factors at irradiation of $1000 \mathrm{~W} / \mathrm{m}^{2}$ and $25^{\circ} \mathrm{C}$ are summarized in Tables 7 and 8 . These factors are defined as follows:

$T_{1}$ is the maximum point reaching time (Sec);

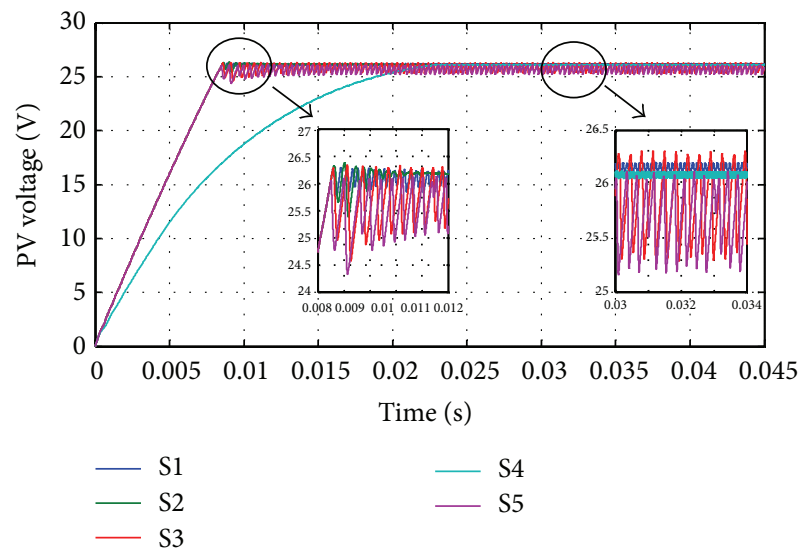

Figure 16: PV voltage at irradiation of $1000 \mathrm{~W} / \mathrm{m}^{2}$ and $25^{\circ} \mathrm{C}$.

$T_{S}$ is the maximum point reaching steady state time $(\mathrm{Sec})$;

$P_{\text {ave }}$ is the average power (W);

$P_{\text {ripp }}$ is the ripple in power in time $T_{1}(\mathrm{~W})$;

$P_{\text {ripp_S }}$ is the ripple in power in time $T_{s}(\mathrm{~W})$;

$V_{\text {ave }}$ is the average voltage $(\mathrm{V})$;

$V_{\text {ripp }}$ is the ripple in voltage in time $T_{1}(\mathrm{~V})$;

$V_{\text {ripp_S }}$ is the ripple in voltage in time $T_{s}(\mathrm{~V})$;

$I_{\text {ave }}$ is the average current (A); 


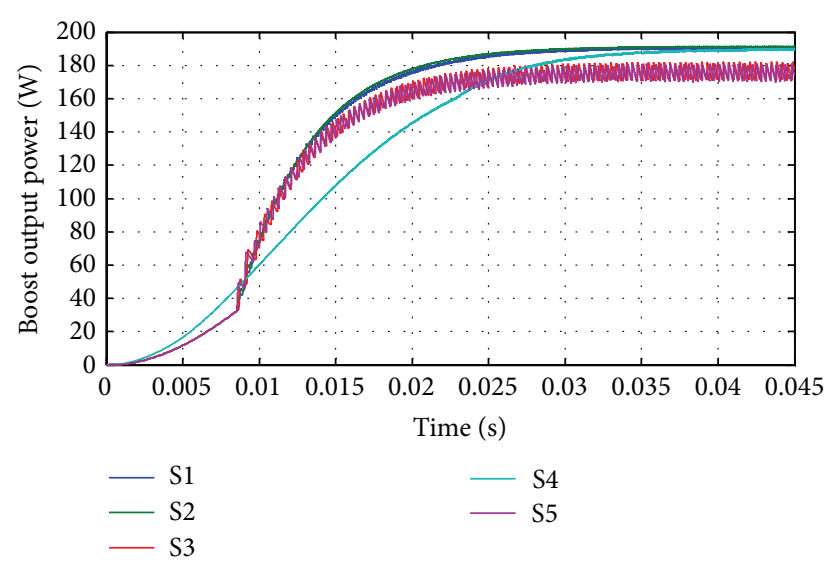

FIGURE 17: Boost output power at irradiation of $1000 \mathrm{~W} / \mathrm{m}^{2}$ and $25^{\circ} \mathrm{C}$.

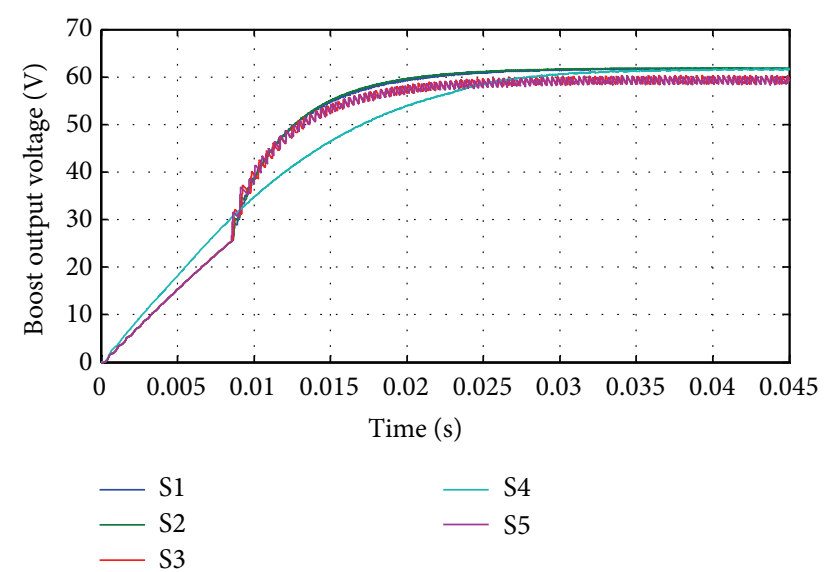

FIGURE 18: Boost output voltage at irradiation of $1000 \mathrm{~W} / \mathrm{m}^{2}$ and $25^{\circ} \mathrm{C}$.

$I_{\text {ripp }}$ is the ripple in current at steady state time (A); $\eta_{T}$ is the efficiency (\%).

In Figure 15, the PV available maximum power at irradiation of $1000 \mathrm{~W} / \mathrm{m}^{2}$ and $25^{\circ} \mathrm{C}$ for different fuzzy subsets is shown. In all subsets, the maximum power point is obtained after a small stilling time for S1, S2, and S4 with the average value of 200 watts that is exact value according to data sheet, but, for S3 and S5, the values are 199.3 and 199 watts, respectively. As shown in Figure 15 and Table 7, the MPP is obtained at $0.0085\left(T_{1 P}\right.$ PV $)$ second for S1, S2, S3, and S5, but, for S4, it is 0.022 second. Other than that, S2 has the lower steady state time for obtaining MPP. The important point is that, in $T_{1 P}$, there are oscillations $\left(P_{\text {ripp PV }}\right)$ in power for S1, S2, S3, and S5 with values of $0.3,1.2,4.2$, and 5.4 watts, respectively, that can lead to some losses, but, for S4, the power oscillation is zero from the first time that MPP is obtained. The power ripple at steady state time of MPP is zero for S1, S2, and S4, but, for S3 and S5, the values are 1.4 and 1.9 watts, respectively.

The PV available maximum voltage at $1000 \mathrm{~W} / \mathrm{m}^{2}$ and $25^{\circ} \mathrm{C}$ for different subsets is shown in Figure 16. According to

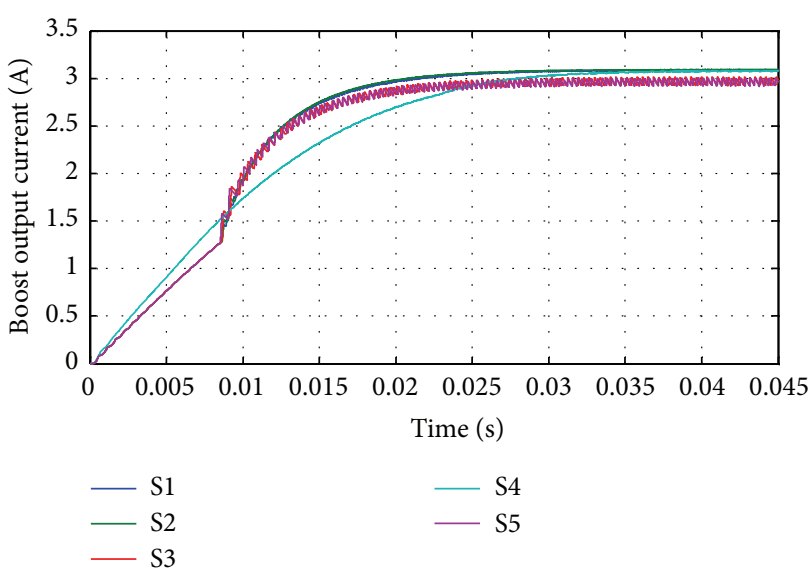

FIGURE 19: Boost output current at irradiation of $1000 \mathrm{~W} / \mathrm{m}^{2}$ and $25^{\circ} \mathrm{C}$.

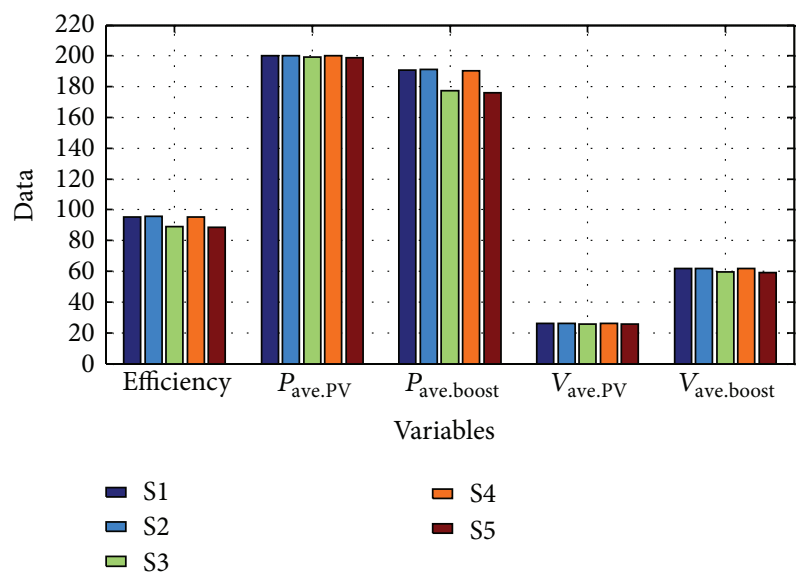

Figure 20: The bar graph for PV variables.

this figure and Table 7, the time for reaching the maximum point of voltage for S4 is more than other subsets but this subset has the minimum ripple voltage value in $T_{1 \mathrm{~V}}$ and approximately in $T_{\mathrm{SV}}$.

In Figures 17 and 18, the output power and voltage of the system are shown. According to these figures and Table 8, S1, S2, and S4 have much more average power in comparison with S3 and S5 as the main reason is bigger oscillations in power and voltage. $\mathrm{S} 2$ has the minimum ripple in power and voltage that are 0.7 watt and 0.1 volt, respectively.

The output currents for all subsets are shown in Figure 19. According to this figure and Table 8, S2 has the maximum average value and also the minimum ripple in current. S4 is the next subset that has maximum average current value and the minimum ripple in current.

Another important factor for selecting the best fuzzy subset is the efficiency of the system that is defined by ratio of the output power to input power of the system. Among the discussed subsets, S2 has the maximum efficiency with $95.7 \%$ and S5 has the minimum one with $88.52 \%$.

In Figures 20 and 21, the bar graphs of this comparative study are plotted that is beneficial for better general survey. 


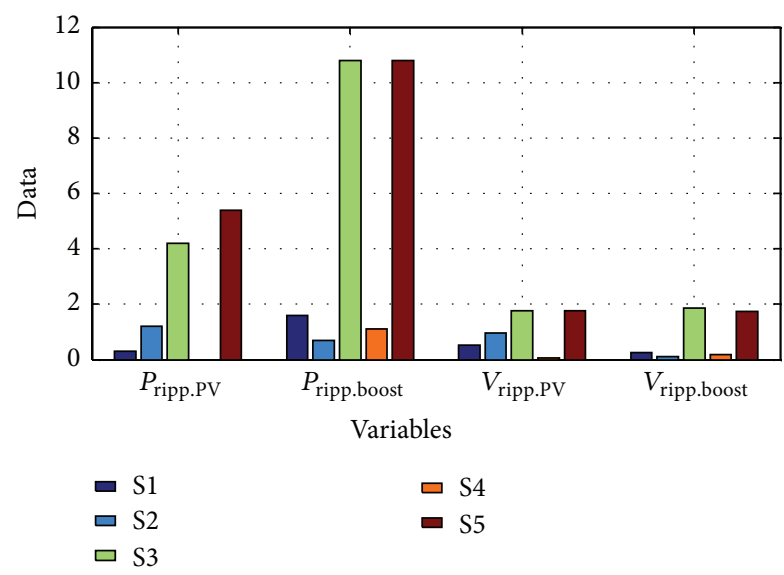

FIgURE 21: The bar graph for boost converter variables.

According to these graphs and Tables 7 and 8, S2 and S4 have the better performance among all subsets. In comparison between $\mathrm{S} 2$ and $\mathrm{S} 4$, the maximum power point reaching time for S2 is less than S4 that is so important for controller to track the MPP. The ripple values of power and voltage are important when the MPP is obtained so that the minimum ripple value makes a significant reduction in switching and power losses. According to Table 7, S4 and S2 have the minimum ripple values in MPP's reaching time, respectively. So, considering all above analyzed factors, it can be concluded that $S 2$ is the best fuzzy subset which can track MPP in minimum time and low oscillation with high efficiency.

\section{Conclusion}

This paper presents a detailed comparative survey of five general fuzzy logic subsets that are used for fuzzy logic (FL) based on maximum power point tracking technique. In this work, simulation has been done in MATLAB. The main objective of this work was to obtain the most efficient fuzzy subset among the general FL subsets used for FLC in boost converter applications. The obtained results show that the rules and range of membership functions are so significant for implementing the fuzzy logic controller in the main system. By considering the main factors for different subsets in same conditions, it is observed that second and fourth subsets have better performance in comparison with other subsets. The second subset (S2) has minimum MPP's reaching time and zero ripple value for power at steady state time with maximum efficiency. The fourth subset (S4) has the minimum ripple in voltage and current at reaching time of MPP but it needs much more time for reaching the MPP. Therefore, considering all above analyzed factors, it can be concluded that $\mathrm{S} 2$ is the best fuzzy subset which can track MPP in minimum time and low oscillation with high efficiency.

\section{Conflict of Interests}

The authors declare that there is no conflict of interests regarding the publication of this paper.

\section{References}

[1] R. Faranda and S. Leva, "Energy comparison of MPPT techniques for PV systems," WSEAS Transactions on Power Systems, vol. 3, pp. 446-455, 2008.

[2] N. Khaehintung, P. Sirisuk, and A. Kunakorn, "Grid-connected photovoltaic system with maximum power point tracking using self-organizing fuzzy logic controller," in Proceedings of the IEEE Region 10 Conference (TENCON '05), pp. 1-4, November 2005.

[3] S. Lalouni, D. Rekioua, T. Rekioua, and E. Matagne, "Fuzzy logic control of stand-alone photovoltaic system with battery storage," Journal of Power Sources, vol. 193, no. 2, pp. 899-907, 2009.

[4] L. Castaner and S. Silvestre, Modelling Photovoltaic Systems Using PSpice, John Wiley and Sons, New York, NY, USA, 2002.

[5] M. Masoum and M. Sarvi, "Design, simulation and construction of a new fuzzy-based maximum power point tracker for photovoltaic applications," in Proceedings of the Australasian University Power System Engineering Conference (AUPEC '02), 2002.

[6] C.-Y. Won, D.-H. Kim, S.-C. Kim, W.-S. Kim, and H.-S. Kim, "A new maximum power point tracker of photovoltaic arrays using fuzzy controller," in Proceedings of the 25th Annual IEEE Power Electronics Specialists Conference (PESC '94), vol. 1, pp. 396-403, Taipei, Taiwan, June 1994.

[7] J. Ma, K. L. Man, T. Ting, N. Zhang, S.-U. Guan, and P. W. H. Wong, "Approximate single-diode photovoltaic model for efficient I-V characteristics estimation," The Scientific World Journal, vol. 2013, Article ID 230471, 7 pages, 2013.

[8] B. K. Bose, P. M. Szczesny, and R. L. Steigerwald, "Microcomputer control of a residential photovoltaic power conditioning system," IEEE Transactions on Industry Applications, vol. 21, no. 5, pp. 1182-1191, 1985.

[9] D. T. Cotfas and P. A. Cotfas, "A simple method to increase the amount of energy produced by the photovoltaic panels," International Journal of Photoenergy, vol. 2014, Article ID 901581, 6 pages, 2014.

[10] O. Wasynczuk, "Dynamic behavior of a class of photovoltaic power systems," IEEE Transactions on Power Apparatus and Systems, vol. 102, no. 9, pp. 3031-3037, 1983.

[11] D. J. Caldwell, L. T. Bavaro, and P. J. Carian, "Advanced space power system with optimized peak power tracking," in Proceedings of the 26th Intersociety Energy Conversion Engineering Conference (IECEC '91), vol. 2, pp. 145-150, August 1991.

[12] H. Yongji and L. Deheng, "A new method for optimal output of a solar cell array," in Proceedings of the IEEE International Symposium on Industrial Electronics, pp. 456-459, 1992.

[13] L. Fang, X. Hengwei, K. Yong, and D. Shangxu, "A variable step maximum power point tracking method using differential equation solution," in Proceedings of the 2nd IEEE Conference on Industrial Electronics and Applications (ICIEA '07), pp. 22592263, May 2007.

[14] R. Wai, W. Wang, and C. Lin, "High-performance standalone photovoltaic generation system," IEEE Transactions on Industrial Electronics, vol. 55, no. 1, pp. 240-250, 2008.

[15] A. Goetzberger and V. U. Hoffmann, Photovoltaic Solar Energy Generation, vol. 112, Springer, New York, NY, USA, 2005.

[16] S. W. Angrist, Direct Energy Conversion, 1976.

[17] J. A. Gow and C. D. Manning, "Development of a photovoltaic array model for use in power-electronics simulation studies," IEE Proceedings: Electric Power Applications, vol. 146, no. 2, pp. 193-200, 1999. 
[18] KC200GT Solar Panel, http://www.kyocerasolar.com.

[19] R. W. Erickson and D. Maksimovic, Fundamentals of Power Electronics, Springer, New York, NY, USA, 2001.

[20] R. M. Hilloowala and A. M. Sharaf, "A rule-based fuzzy logic controller for a PWM inverter in photo-voltaic energy conversion scheme," in Proceedings of the 28th Annual Meeting of the IEEE Industry Applications Conference, pp. 762-769, October 1993.

[21] N. Khaehintung, K. Pramotung, B. Tuvirat, and P. Sirisuk, "RISC-microcontroller built-in fuzzy logic controller of maximum power point tracking for solar-powered light-flasher applications," in Proceedings of the 30th Annual Conference of IEEE Industrial Electronics Society (IECON '04 ), pp. 2673-2678, November 2004.

[22] C.-Y. Won, D.-H. Kim, S.-C. Kim, W.-S. Kim, and H.-S. Kim, "A new maximum power point tracker of photovoltaic arrays using fuzzy controller," in Proceedings of the 25th Annual IEEE Power Electronics Specialists Conference (PESC '94), vol. 1, pp. 396-403, Taipei, Taiwan, June 1994

[23] M. M. Algazar, H. Al-Monier, H. A. El-Halim, and M. E. E. K. Salem, "Maximum power point tracking using fuzzy logic control," International Journal of Electrical Power and Energy Systems, vol. 39, no. 1, pp. 21-28, 2012.

[24] M. F. Ansari, S. Chatterji, and A. Iqbal, "Fuzzy logic-based MPPT controllers for three-phase grid-connected inverters," International Journal of Sustainable Energy, vol. 32, no. 3, pp. 186-195, 2013.

[25] M. Ajaamoum, M. Kourchi, R. Alaoui, and L. Bouhouch, "Fuzzy controller to extract the maximum power of a photovoltaic system," in Proceedings of the 1st International Renewable and Sustainable Energy Conference (IRSEC '13), pp. 141-146, March 2013.

[26] D. Beriber and A. Talha, "MPPT techniques for PV systems," in Proceedings of the 4th International Conference on Power Engineering, Energy and Electrical Drives (POWERENG '13), pp. 1437-1442, 2013.

[27] L. Donghui and Z. Xiaodan, "Research on fuzzy controller for photovoltaic power system," in Proceedings of the International Conference on Electric Information and Control Engineering (ICEICE '11), pp. 3506-3509, 2011.

[28] M. A. Eltawil and Z. Zhao, "MPPT techniques for photovoltaic applications," Renewable and Sustainable Energy Reviews, vol. 25, pp. 793-813, 2013.

[29] R. Garraoui, L. Sbita, and M. Ben Hamed, "MPPT controller for a photovoltaic power system based on fuzzy logic," in Proceedings of the 10th International Multi-Conference on Systems, Signals and Devices (SSD '13), pp. 1-6, March 2013.

[30] H. Ibrahim and M. Ibrahim, "Comparison between fuzzy and $\mathrm{P} \& \mathrm{O}$ control for MPPT for photovoltaic system using boost converter," Journal of Energy Technologies and Policy, vol. 2, no. 6, pp. 1-11, 2012.

[31] M. Taherbaneh, A. H. Rezaie, H. Ghafoorifard, K. Rahimi, and M. B. Menhaj, "Maximizing output power of a solar panel via combination of sun tracking and maximum power point tracking by fuzzy controllers," International Journal of Photoenergy, vol. 2010, Article ID 312580, 13 pages, 2010.

[32] H. Mahamudul, M. Saad, and M. Ibrahim Henk, "Photovoltaic system modeling with fuzzy logic based maximum power point tracking algorithm," International Journal of Photoenergy, vol. 2013, Article ID 762946, 10 pages, 2013.

[33] M. S. Ngan and C. W. Tan, "A study of maximum power point tracking algorithms for stand-alone photovoltaic systems," in
Proceedings of the IEEE Applied Power Electronics Colloquium (IAPEC '11), pp. 22-27, April 2011.

[34] S. Sreekumar and A. Benny, "Maximum power point tracking of photovoltaic system using Fuzzy Logic Controller based boost converter," in Proceedings of the International Conference on Current Trends in Engineering and Technology (ICCTET '13), pp. 275-280, 2013.

[35] R. Vinifa and A. Kavitha, "Fuzzy based maximum power point tracking on a PV system," in Proceedings of the International Conference on Energy Efficient Technologies for Sustainability (ICEETS '13), pp. 329-333, Nagercoil, India, April 2013. 

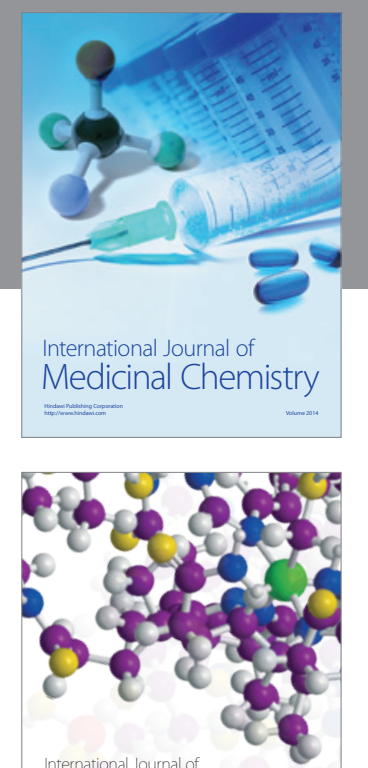

\section{Carbohydrate} Chemistry

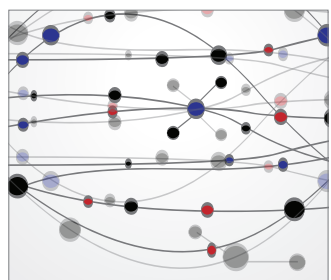

The Scientific World Journal
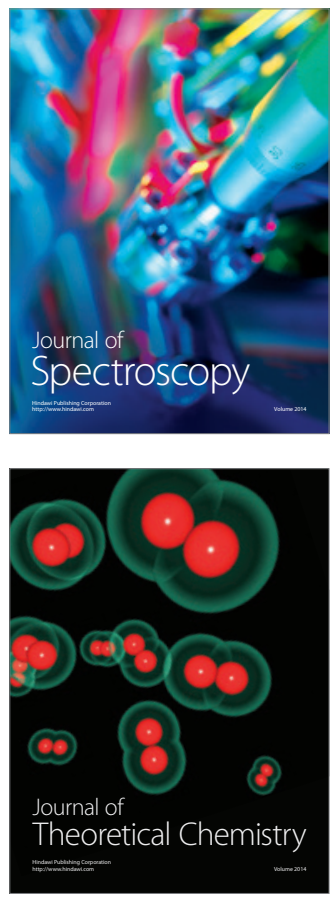
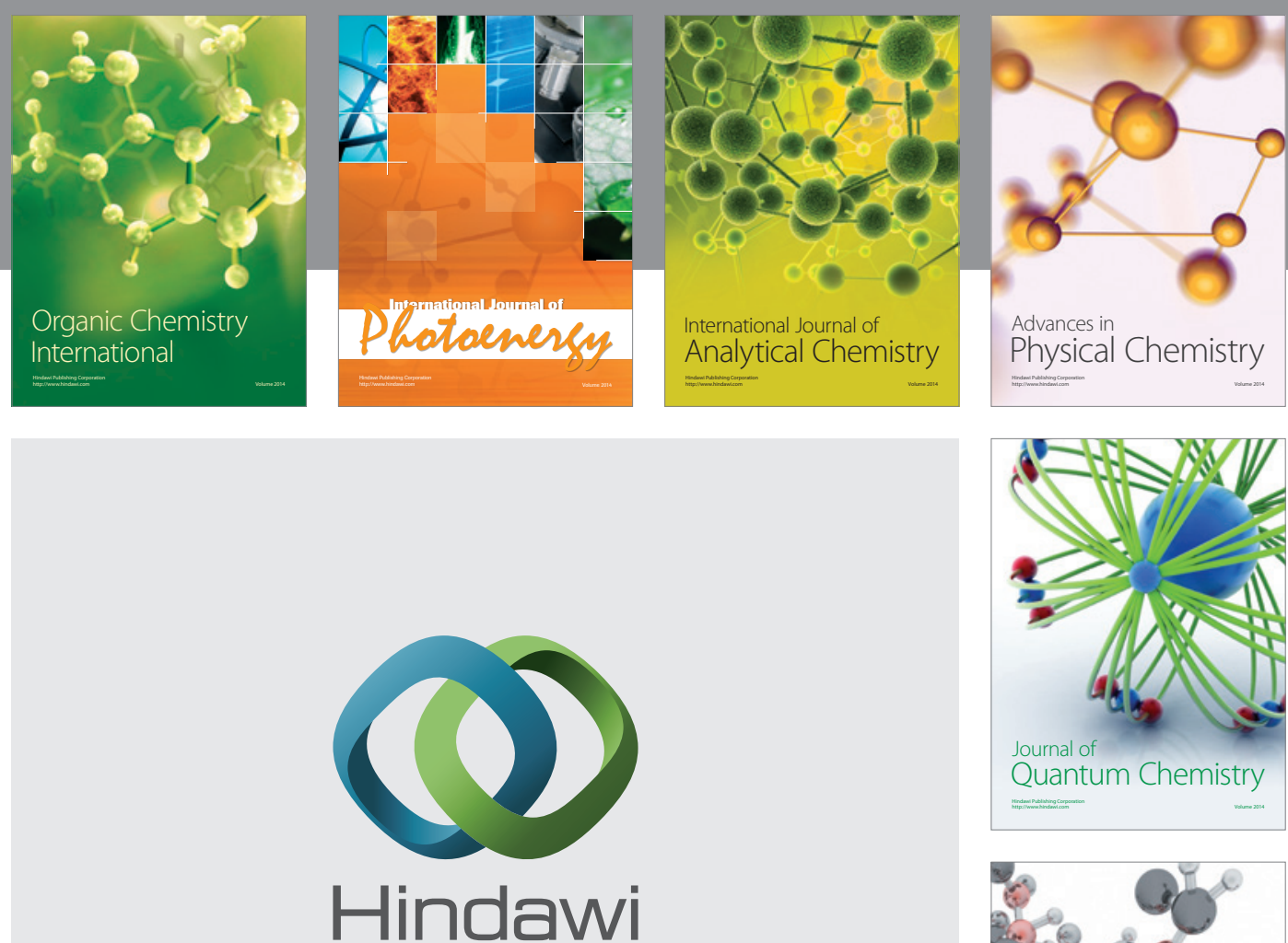

Submit your manuscripts at

http://www.hindawi.com

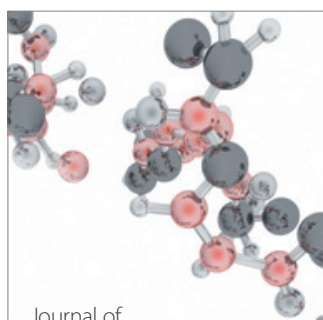

Analytical Methods

in Chemistry

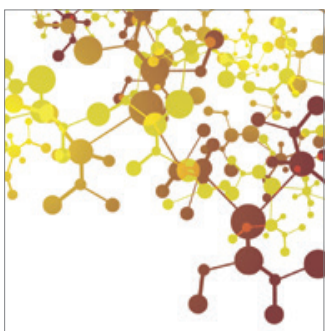

Journal of

Applied Chemistry

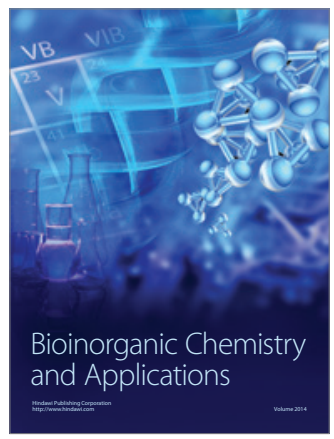

Inorganic Chemistry
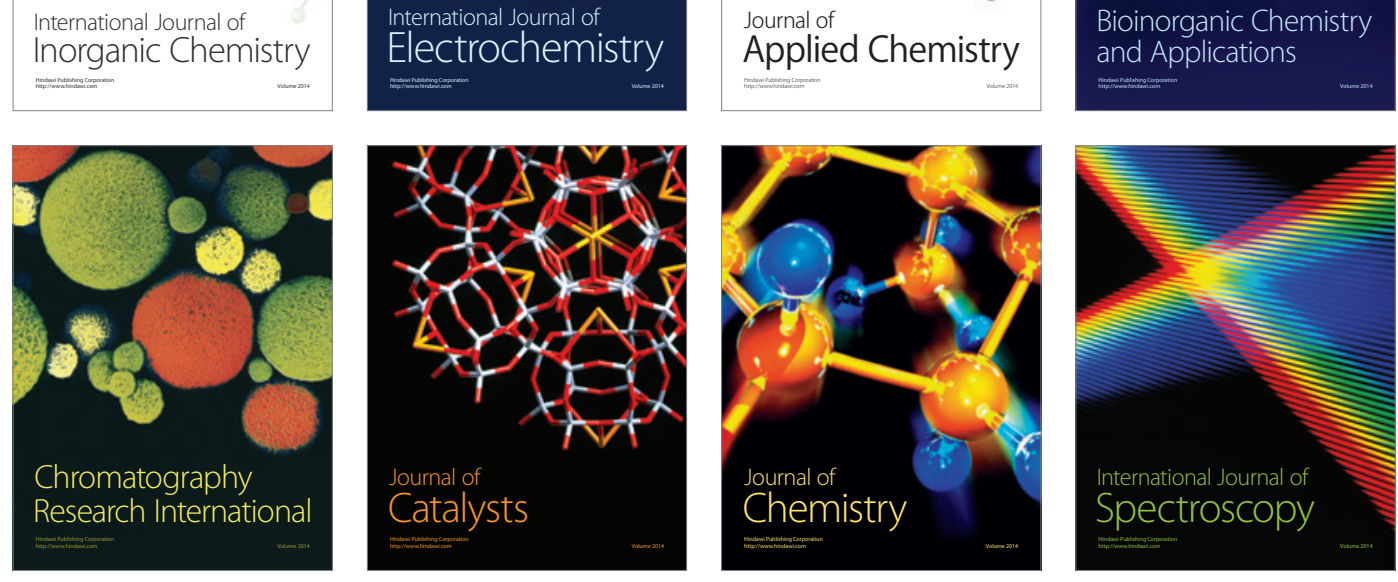